(昭和 48 年 7 年 2 日受理)

$$
\begin{aligned}
& \text { アルコールのヒドロトロピーについて } \\
& \text { 信州大学㵶維学部 三石賢 - 南部育 } \\
& \text { 石井直子 }
\end{aligned}
$$

\title{
ON THE HYDROTROPIC BEHAVIOURS OF ALCOHOLS
}

\author{
By Masanu Mitsuishi, Sodatsu Nanbu and Naoko Ishii \\ Faculty of Textile Science and Technology, Shinshu University \\ Ueda, Nagano Prefecture
}

The solubilities of 1-aminoanthraquinone(MAAQ), 1,4-diaminoanthraquinone(DAAQ) and 1,4,5,8-tetraaminoanthraquinone(TAAQ) in water and in the mixtures of water and alcohols such as methanol, ethanol and n-propanol were determined at $20,25,30,40$ and $50^{\circ} \mathrm{C}$. From the solubility data the thermodynamic parameters for the transfer of aminoanthraquinone compounds(AAQ) from water to the water-alcohol mixtures were calculated.

On the basis of the thermodynamic parameters, the hydrotropic behaviours of alcohol on the AAQ's are discussed. The following results were obtained:

(1) The solubilities of the AAQ's were larger in water-alcohol mixtures than in water. The effects of alcohols on the solubilities of the AAQ's increase in the order of methanol, ethanol and n-propanol.

(2) The free energy changes were negative. As to the number of amino groups in the AAQ and the alcohol, the enthalpy changes were found to vary from about +4.5 to $-5.8 \mathrm{Kcal} / \mathrm{mol}$ and the entropy changes from about +17 to $-13 \mathrm{cal} / \mathrm{deg}$. mol. alcohol.

(i) The enthalpy and entropy changes of the MAAQ were positive in all the mixtures of water and

(ii) The enthalpy and entropy changes of the DAAQ were positive in water-methanol mixtures, and they were negative in water-ethanol and in water-n-propanol mixtures.

(iii) The enthalpy and entropy changes of the TAAQ were negative in all the mixtures of water and alcohols.

(iv) The enthalpy change of AAQ was found to decrease with the increase in the length of alkyl chain of alcohols.

(3) Assuming the presence of ice-like structure of water around the MAAQ and alcohol molecules, the positive enthalpy and entropy changes can be explained by means of hydrophobic interactions between the hydrophobic portions of the MAAQ and alcohol molecules. The negative enthalpy changes for the transfer of the AAQ's cotaining two or four amino groups may suggest that the adduct between the AAQ and alcohol is formed to be hydrated.

(Received July 2, 1973)

\section{1. 緒霅}

ヒドロトロピーの機構は二つの立場から検討されてい るとみることができる。その一つは主としてヒドロトロ ーブ剤の分子檴造に着目してその作用機構を明らかにし ようと試みて扔り”，他は主としてヒドロトローブ剂を 含む溶液に着目してとドロトロピ一を取り报っている゙う。 著者らはこれら両者とはわずかに観点をかえて種々の 数の特定嘿換基（たとえばフミ，基）を含む一建の化合 物を被ヒドロトローブ斉として選んでアルュールのヒド ロトロピーについて检討しようと考えた。すなわち，被
ヒドロトロープ剂としては，アミノ基の置換数が $1 ， 2$ および4個のアミノアントラキノン化合物を用い，それ らの化合物の純水，水とメタノ一ル，エタノールおよび $n$ ープロパールとの混合系での溶解度から，溶解過程 の熱力学的バラメータを求め, その結果に基づいてヒド ロトロピーの機溝について考察した。

\section{2. 実験試料と方法}

\section{1. アミノアントラキノン化合物}

本実験に用いたアミノアントラキノン化合物（AAQ と略記する)は 1 アミノアントラキノン（MAAQと 
Table 1 Aminoanthraquinone Compounds used in the experiment.

\begin{tabular}{l|c|cc}
\hline \multicolumn{1}{c|}{ Aminoanthraquinone Compounds } & $\begin{array}{c}\text { Melting points } \\
{ }^{\circ} \mathrm{C}\end{array}$ & $\begin{array}{c}\text { Nitrogen contents (\%) } \\
\text { obs. }\end{array}$ \\
\hline 1-aminoanthraquinone & 253 & 6.26 & 6.27 \\
1,4 -diaminoanthraquinone & & 11.76 \\
$1,4,5,8$-tetra-aminoanthraquinone* & 267 & 11.34 & 11.76 \\
\hline
\end{tabular}

* Commercial compounds were supplied by Mitsui-Toatsu Chemical Industries $\mathrm{Co}$.

略記する)，1，4ーシアミノアントラキノン(DAAQ と略記する)拈よび $1 ， 4 ， 5 ， 8$-テトラフミノアント ラキノン ( T A A Q と略記する)の3 種類であっていず れもEgertonら"と同様な方法によって精製した。 Table 1 には3 種のAAQの融点拉よび窒素含量を示した。

\section{2 アルコール類}

本実験に用いたアルコール類はメタノール，エタ， 一ルおよびnーブロパールであっていずれも市骐試薬 特級品をそのまま用いた。

\section{3 溶解度の測定}

水および水ーフルコール采への A AQの溶解度は次の ように求めた。すなおち適量の A AQ を所定濃度の溶媒 に加え，桓温槽中に設置した振燙機を用いて数時間振湯 した後、溶解平衡に達するまで3日間放置した。ついで 沈渐上の上澄夜を採取し，ガラスフィルターNo.4を用 いてロ過し，同種のアルコールで希釈後，分光光度計( 島 建製作所製光電分光光度計 QV - 50 型)を用いて比色法 によって漂度を決定し溶解度を求めた。なお、アルコー ルの濃度は $0.031 ， 0.061 ， 0.092 ， 0.122$ および 0.153

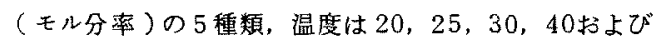
$50 \pm 0.1^{\circ} \mathrm{C}$ に损いて测定を行なった。

\section{3. 実験結果および考察}

フルコールのモル分率が $0.031 ， 0.061 ， 0.092 ， 0.122$ 扔よび0.153の水とみ夕ノ一ル，士タノ一ル扰よ゙゙nブロバールとの混合系括よび純水中に拈けるMAAQ， $\mathrm{DAAQ}$ おむ゙ T AAQの溶解度を $20 ， 25 ， 30 ４ 0$ 拈よ

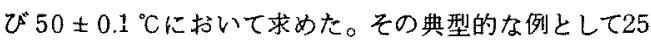
${ }^{\circ} \mathrm{C}$ における溶解度曲線を Fig.1に示した。

Fig.1から次のことがわかる。

（1）水ーアルコール采中に拈けるMAAQ，DAAQ拉 よびT A AQの焀解度は純水中におけるそれよりも大き く，フルコールの混合割合が大になるにしたがって增加 する。

(ii） AAQの溶解度に対するアルコールの効果は， ‘ タノール，エタノール，拈よびnープロパノールの順序 で大きくなる。

これらと同様なアルコールのとドロトロープ効果はし

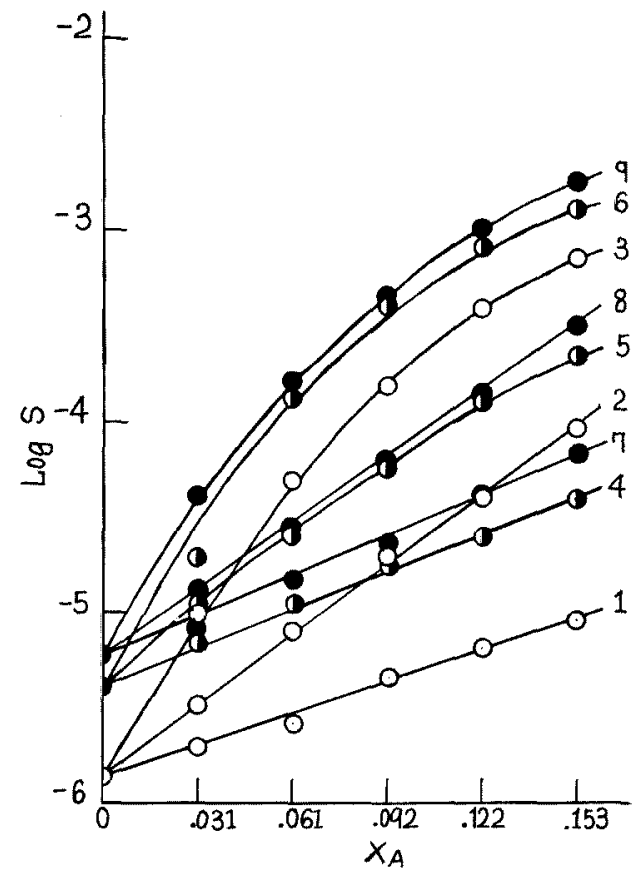

Fig. 1 Solubilities of aminoanthraquinone compounds in water-alcohol mixtures $\left(X_{A}\right.$ : mole fraction of alcohol) at $25^{\circ} \mathrm{C}$.

1. 1-aminoanthraquinone in water-methanol mixtures.

2. 1-aminoanthraquinone in water-ethanol mixtures.

3. 1-aminoanthraquinone in water ${ }^{-n-p r o-}$ panol mixtures.

4. 1, 4-diaminoanthraquinone in watermethanol mixtures.

5. 1,4-diaminoanthraquinone in watere thanol mixtures.

6. 1,4-diaminoanthraquinone in water-npropanol mixtures.

7. $1,4,5,8$-tetra-aminoanthraquinone in water-methanol mixtures.

8. 1, 4, 5, 8-tetra-aminoanthraquinone in water-ethanol mixtures.

9. 1, 4, 5, 8-tetra-aminoanthraquinone in water-n-propanol mixtures. 
ばしば認められているが、，AAQの溶解に対してアル コールが有効に作用すること，执よびその溶解に対して アルコールのアルキル基が重要な役割を果していること が推定できる。

これらの実験結果が提供する情報を詳細に検討するた わに，水系中のA AQを水一アルュール混合系中へ移寸に 伴う自由エネルギ一変化, $\Delta F_{t r}$ ， エンタルピ一変化， $\Delta H_{t r}$ ，およびェントロピー変化， $\Delta S_{t r}$ ををれぞれ $(1)$ ， （2）および（3）式から求めた。すなわち，

$$
\begin{aligned}
& \Delta F_{t r}=-R T \ln \left(\frac{S_{W A}}{S_{W}}\right) \\
& \Delta H_{t r}=-R \frac{d \ln \left(\frac{S_{W A}}{S_{W}}\right)}{d\left(\frac{1}{T}\right)} \\
& \Delta S_{t r}=\frac{1}{T}\left(\Delta H_{t r}-\Delta F_{t r}\right)
\end{aligned}
$$

ここで $S_{W}$ および $S_{W A}$ はそれぞれ A A Q の純水および水 ーフルコール系における溶解度である。

(1) 式から求めた $\Delta F_{t r}$ に性有意と思われる温度依存性 が認めら扎た（2）式にしたがって $\ln \left(S_{W A} / S_{W}\right)$ を 1/Tに対してブロットした図はほぼ直線を与えることが かかったので， $\Delta H_{t r}$ には有意な温度依存性はないことが わかった。そこでTable 2 には $\Delta F_{t r}$ の温度依存性につ

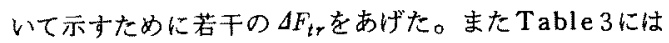
(1) 〜 (3) 式によって求めた熱力学的バラィータのうち. $25^{\circ} \mathrm{C}$ ，アルコールのモル分率が 0.092 に拈りる結果を例 として示した。

Table 2 拉よび 3 から次のことがわかる。

（i）MAAQの水一メ夕ノール，水一エタノールおよ び水ーnーブロパノール系への移行に伴う $\Delta F_{t r}$ 法温度が 上昇するにしたがってて，その負値が大きくなる。 $25^{\circ} \mathrm{C}$ におけるMAAQの $\Delta H_{t}$ と $\Delta S_{t}$ とは全ての本一

Table 2 Temperature dependences of some of free energy changes (cal/mol)

\begin{tabular}{|c|c|c|c|c|c|c|}
\hline \multirow{2}{*}{ Mixtures } & Alcohol & & \multicolumn{4}{|c|}{ Temperature $\left({ }^{\circ} \mathrm{C}\right)$} \\
\hline & (mol fraction) & 20 & 25 & & 40 & 50 \\
\hline \multicolumn{7}{|c|}{ 1-aminoanthraquinone } \\
\hline Water-me thanol & 0.061 & -320 & -360 & -450 & -600 & -720 \\
\hline Water-ethanol & 0.061 & -960 & -1020 & -1060 & -1150 & -1220 \\
\hline Water-n-propanol & 0.061 & -2060 & -2090 & -2130 & -2170 & -2250 \\
\hline \multicolumn{7}{|c|}{ 1, 4-diaminoanthraquinone } \\
\hline Water-me thanol & 0.092 & -880 & -890 & -890 & -900 & -890 \\
\hline Water-ethanol & 0.092 & -1600 & -1590 & -1610 & -1590 & -1540 \\
\hline Water-n-propanol & 0.092 & -2810 & -2770 & -2680 & -2640 & -2540 \\
\hline \multicolumn{7}{|c|}{$1,4,5,8-t$ etra-aminoan thraquinone. } \\
\hline Water-methanol & 0.122 & -1240 & -1190 & -1150 & -1050 & -970 \\
\hline Water-ethanol & 0.122 & -1950 & -1910 & -1890 & -1870 & -1690 \\
\hline Water-n-propanol & 0.122 & -3460 & -3220 & -3130 & -3070 & -2990 \\
\hline
\end{tabular}
for the transfer of aminoanthraquinone compounds from water to wateralcohol mixtures.

Table 3 Free energy changes $\left(\Delta F_{t r}\right)$, enthalpy changes $\left(\Delta H_{t r}\right)$ and entropy changes $\left(\Delta S_{t r}\right)$ for the transfer of aminoanthraquinone compounds from water to water alcohol mixtures (alcohol mol fraction : 0.092) at $25^{\circ} \mathrm{C}$.

\begin{tabular}{l|c|c|c}
\hline \multicolumn{1}{c|}{ Mixtures } & $\Delta F_{t r} \mathrm{cal} / \mathrm{mol}$ & $\Delta H_{t r} \mathrm{cal} / \mathrm{mol}$ & $\Delta S_{t r} \mathrm{cal} / \mathrm{deg} \cdot \mathrm{mol}$ \\
\hline & $1-$ aminoanthraquinone & +4500 & +17 \\
Water-methanol & -690 & +2900 & +15 \\
Water-ethanol & -1550 & +2030 & +16 \\
Water-n-propanol & -2770 & +2030 & +10 \\
\hline \multicolumn{2}{l}{} & $1,4-$ diaminoant hraquinone & -1 \\
Water-methanol & -880 & -1890 & -1 \\
Water-ethanol & -1600 & -2910 & -4 \\
Water-n-propanol & -2740 & -2030 & -13 \\
\hline
\end{tabular}


アルコール系に抬いてともに正の值を示す。また $\Delta H_{t r}$ は かタノール, エタノール, nープロパノールの順, すな わち，フルコールのアルキル基が大きくなるにしたがっ て滅少する。

(ii) $\mathrm{DAAQ}$ 水加的水一メタノ一ル采へ移るに伴う $\Delta F_{t r}$ は温度が上昇するにしたがって，その負值はわずか に增加する傾向にある。しかし，水一エタノール系の場合 には $\Delta F_{t r}$ は温度によってほとんど变わらず，水一nープ ロハンール系の場合は温度の上昇とともにわずかに娍少 する。 $\Delta H_{t r}$ 邨び $\Delta S_{t r}$ は水ーエタノール，水ー $n-フ ゚$ ロバール系に拟てはともに負となる。また $\Delta H_{t}$ は ג タノール, エタノール, nープロパノールの順序で减少 する。

(iii) TAAQの $\Delta F_{t r}$ は水一メタノール，本一ェタノー ル, 水一nープロパノール系に扔いて，その負值が温度 の上昇とともに小さくなる。 $\Delta H_{t r}$ 扰び $\Delta S_{t r}$ は全ての

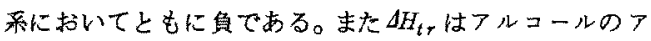
ルキル基が大きくなるにしたがって小さくなる。

(i)〜(iii)に扮いて指摘したように，AAQの水から 水一アルコール系へ移るに伴 $5 \Delta F_{t r} ， \Delta H_{t r}$ 捄ざ $\Delta S_{t r}$ 住 $\mathrm{AAQ}$ 分子中に含まれているアミ，基の数とアルコ一 ルの種類に依存している。

また 3 種の A AQ に共通な結果としては次のことがあ げられる。

(iv) アルコールのフルキル基が大きくなるにしたがっ て $\Delta F_{t r}$ の負值が大きくなる。

（V）フルコールのアルキル基が大きくなるにしたがっ て $\Delta H_{t r}$ 林堿少する。

(iv)および(V)にあげた結果は，当然 A AQの溶解に はフルコールのアルキル基が重要な役割を果しているこ とを示唆している。

(、)にあげた結果は，アげ゙ンゼンの溶解に対するア ルコールの効果の際に見られる $\Delta H_{t}$ の傾向" とは対照的 である。(V)にあげた結果は，AAQの水ーアルコール 系への溶解には，AAQとアルコールとの間に発熱的相 互作用が存在することを示唆している。

ここで，SH 化 $\Delta H_{t r(E \times 0)}$ と吸熱的相互作用によるエンタルピー变化 $\Delta H_{t r}$ (END)との和によって表わして考察をすすめる。す なわち。

$$
\Delta H_{t r}=\Delta H_{t r}(E \times O)+\Delta H_{i r(E N D)}
$$

ただし, $\Delta H_{\operatorname{tr}(\text { EXO) }}<0$

$$
\Delta H_{t r(\text { END })}>0
$$

である。

$\Delta H_{t r(\mathrm{ExO})}$ の原因となるような相互作用としては， $\mathrm{AAQ}$ 分子の構造加ら考元て，双極子一双極子相互作用，
双掼子 - 誘起双極子相互作用など極性 van der Waals 力に上る相互作用，無極性 van der Waals力による相 互作用捛よび A A Q 分子と溶媒成分との間の水素結合に

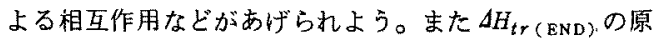
因となる相互作用としては，溶媒構造の変化，たとえば 水の 3 次元構造 ${ }^{* 1}$ の減少，溶媒成分間の木素結合の切断 などが考允られる。この水の 3 次元構造の减少は $\mathrm{AAQ}$ とアルコール分子との踈水的相互作用*3 の存在を意味し， $\Delta H_{t r(\mathrm{END})}$ には正の $\Delta S_{t r}$ が伴なうのが一般である。

この上らな種々の原因によって生じる $\Delta H_{t r(E \times O)}$ と $\Delta H_{\text {tr }(\mathrm{END})}$ とが相殺されて， $\Delta H_{t r}$ は正あるいは負となる。 次に上述の $\Delta H_{t}$ の内容を考虑しながら Table 3 の熱力 学的パラメータに基づいてMAAQ，DAAQおよびTAAQ の混合容媒中における溶解機構について考察をすすめた w。

（i）にあげたように 3 種の A AQのうち，ただ 1 個の アミ，基を含むMAAQに限って全ての水一フルコール 系において $\Delta H_{t r}$ 拉よび $\Delta S_{t}$ がともに证值をとる。すな わちMAAQが純本からホーアルコール系へ移る過程は エネルギー的には不利であって, ェントロピー項の寄与 に負う。このことはMAAQの溶解にはMAAQとアル コール分子との間の眯本的相互作用が関与していること を示㖫している。しかし一方に拈いてアルコールのアル キル基が大きくなるにしたがって $\Delta H_{t r}$ の正値が隇少する ことが認められる。これは，アルキル基が大きくなるに

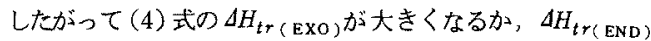
が小さくなるかのいずれか一方，あるいは両方が同時に 起こるためであ万う。この場合，マルキル基の蹅水的性

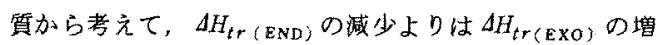
大を考える方が不合理ではないだるら。したがって $\Delta H_{t r}$ がアルキル基の大きくなるとともに减少する原因として はアントラキノン核とアルキル基との間のvan der Waals 力のほかに，ヒドロトロピーの機構に関するRath の考え方の上5にMAAQ分子とアルコール分子から形 成された付加物の極性基に対していくつかの水分子が溶 媒和するような相互作用を考雷するならば，アルコール

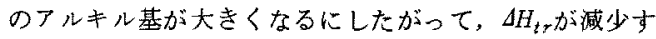
る事実を十分に説明することができるものと考えられる。 （ii）にあげたように2 個のアミ，基を含むDAAQの

*1 水に少量のアルコールを溶解した際に起る熱力学的 諸量から推定して、アルコール分子周边の水は，純 水中に拁けるよりも強力な3次元棈造を組み立てて いるものと考えられている。したがってその水構造 はアルコール分子，あるいは第 3 成分の動向によっ て変化するものと考えられる,

*2 Kauzman-N'eme thy-Scheraga の意味に捕ける hydrophobic interactiont( $5^{7)}$ 。 


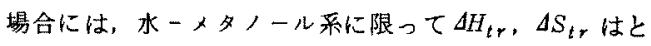
もに正值をとり，他の水一ェタノール，水一 $n$-プロパ ノール系においてはをもに負値を示している。水一メタ

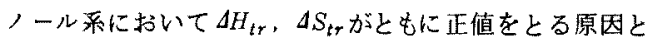
しては，MAAQの筫合と同様な挙動を考えることがで きよう。また $\Delta H_{t r}$ および $\Delta S_{t r}$ がともに負值をとる原因 としては，MAAQの場合よりもさらに大きい $\Delta H_{i r(E x O)}$ の相互作用と，より小さい $\Delta H_{t r(E N D)}$ の相互作用を考虑 しなければならないだろう。

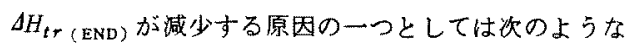
考え万ができる。たとえばAllenら 分光学的検討によって，1構造が共鳴混成体として存在 するものと考えている。I掅造のイオン化した基が周辺 の溶媒の構造を破壊する可能性は十分に考えられるので ${ }^{9}$ ，<smiles></smiles>

(1)

MAAQの場合に考えたような柾水的相互作用による $\Delta H_{t r(E N D)}$ は減少するだる5。

また $\Delta H_{\text {tr(EXO) }}$ の增大の原因としては，同じI 構造の 荷電基と容媒成分の双極子との間には極性 van der Waals 力による相互作用の存在を推定することができ る。そのほかにMAAQよりも 1 個增加しているアミ， 基と溶媒分子との相互作用を考慮すれば $\Delta H_{t r}$ （Exo）の增 大を説明することができよう。これらの $\Delta H_{\text {tr (END) }}$ の减 少と $\Delta H_{t r(\mathrm{ExO})}$ の増大とが相殺されて，結果的には $\Delta H_{t r}$

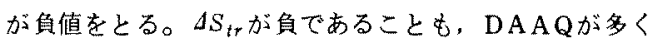
の溶媒分子と結合するであろうことを示唆している。

(iii）にあげたように4個のフミ，基を含む TAAQは MAAQの場合とは全〈対照的な結果を示している。す なわち、 3 種類の水ーアルコール系に抽いて、 $\Delta H_{i}$ 拉よ び $\Delta S_{t r}$ 枚アルュールの混合割合とは関倸なくともに負值 を示している。この $\Delta H_{t r}$ が負值をとるのは $\Delta H_{t r(\mathrm{ExO})}$ が かなり大きいためであらう。その原因としては先ず DAAQ のところで述べたような荷電基と溶媒分子間の極性 van der Waals力による相互作用をあげることがでさよう。 またDAAQよりも2 個增加したアミノ基と溶媒分子と の間の相互作用が考えられる。このような $\Delta H_{\text {tr(Exo) }}$ 原因となる相互作用が大さいことは，AS 値を示寸ことからも納得することができる。

(iv)および (V)にあげたように，3堹類の A AQk共 通した結果としては，それぞれのAAQについて、アル

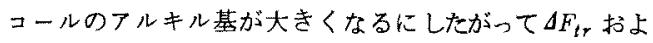

び $\Delta H_{l}$ は次第に減少することである。このことは A AQ 分子とアルコール分子との間にはアルキル基の大きさと

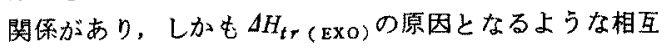
作用が存在することを示唆している。溶液中においては 芳番環に対してアルキル基は平行に近接して存在するこ とについて，いくつかのNMR 分光学的証越が報告され ていることを ${ }^{10,11)}$ 考虑するならば，アントラキノン核に対 してアルコールのアルキル基がvan der Waalsによっ て結合するよらな相互作用を推定することができる。そ のような相互作用は当然，アルキル基の大きいアルコー ルの方が大きいと考えられるので $\Delta H_{t r(\text { Exo) }}$ は大きくな り，安定な付加物を形成するものと考えることができる。 この付加物が溶解するためには付加物中の親水性基に対 して木分子が浴媒和することが必要である。かよらに考 えるならば，安定な付加物を形成しらるマルコール分子 を含む系の方が，安定な水和付加物の形成が可能となり， したがって溶解度は大きくなるものと考えることができる。 以上に述べたようにAAQに対するアルコールのヒト ロトローブ举動は被ヒドロトローブ分子たるAAQの含 むアミ，基の数によってかなり異なることがわかる。 たとえば水に対する容解度が最も小であるMAAQでは $\Delta H_{t r} ， \Delta S_{t r}$ はともに正であるのに対して，2個あるいは4 個のアミノ基を含むDAAQ，T A AQでは $\Delta H_{t r}, \Delta S_{\text {tr }}$ はともに鱼となった。しかし、いずれのAAQでもアル コールのアルキル基が大きくなるにしたがって， $\Delta H_{\text {tr }}$ は 次第に減少する事実加ら，上述のようにフントラキノン 核とアルニル基とが近接した付加物を形成するものと推 諭した。そこでAAQがホーアルコール系に溶解する機 棈としては，Fig. 2に示すようにアントラキノン核に 対してアルコールが結合することによって付加物を形成 し，それに水分子が溶媒和主ることによって溶解するよ うな過程を推定することができる。ただし，Fig.2では 予想されるアミノ基に対する溶媒の結合状態は，四が複 雑となるので省略した。

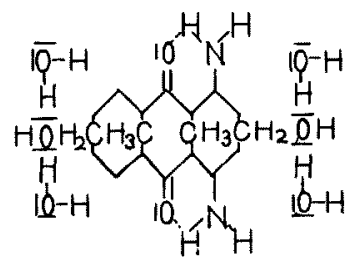

Fig. 2 Hydrotropic behabiour of alcohol on aminoanthraquinone.

4. 総括

$1-$ アミノアントラキノン(MAAQ), 1, 4-ジアミ 
ノフントラキノン (DAAQ)および 1，4，5，8 -テト ラフミノアントラキノン(TAAQ)の水, 水一かタノ一 ル，水一エ夕ノ一ル扰よ゙水一 $n$-プロパノール系への 溶解度をそれぞれ 20〜50 ${ }^{\circ} \mathrm{C}$ に执いて湘定し、アミノア

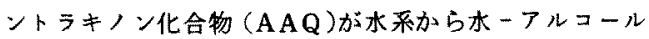
系へ移るに伴う熱力学的バラィータを求め，それに基づ いてフルコールのヒドロトロピーについて唡討したとこ ろ次のような結果が得られた。

（1）いずれのAAQの溶解度も純水よりは7ルコール を含む系にお゙ける方が大きく、ヒドロトロープ効果はx

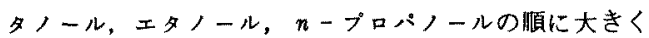
なることがわかった。

（2）いずれの AAQの移行に伴う自由エネルギー変化 も全て負であって，その負值は，フルコールの混合割合 が大きくなるにしたがって，およびアルコールのアルキ 儿基が大きくなるにしたがって，大きくなった。移行に 半らエンタルピー変化，およびエントロピー変化は $\mathrm{AAQ}$ 分子中の丁ミノ基の数とアルコールの種類によってかな り異なることがわかった。

(i) MAAQのエンタルピー変化，エントロピー変化 は，全ての水ーアルコール系に执いて正であった。

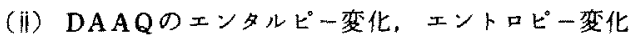
の符号はアルコールの種類によって異なり,メタノール の昜合にはともに正，エタノール，nーブロパノールの 場合にはともに負であった。

(iii) TAAQのエンタルピー変化，エントロピー変化 は全ての水ーアルュール系に扔いてともに負であった。

(iv) エンタルピー变化はアルコールのフルキル基が大 きくなるにしたがって減少した。

（3）（1）および(2)の結果を考慮才扎ば，アミノ基が 1
個のMAAQのヒドロトロピーには践水的相互作用が関与 していると考光られる。またアミ，基が 2 個あるい㤬 4 個 のDAAQあるいはTAAQのアルコールによるヒドロト ロピーには発熱的過程，たとえば広義のvan der Waals 力による相互作用，水素結合による相互作用などが関与 していると考えられる。

\section{参考 文 献}

1）たとえば

H. Rath, J. Rau, D.Wagner ; Melliand Textilber, 43, 718(1962)

H.Rath, J. Rau, D. Wagner : ibid, 44, 969 (1963)

2) たとえば

高岸，片山，黒木；㵶学誌，25，373(1969)

高岸，片山，黑木；同誌，25，381(1969)

3) G. S.Egerton, A.G.Roack ; J.S.D.C.,74, 401(1958)

4) 高岸, 片山，松風，小西，黒木；Kolloid-Z., 232, 699(1969)

5) J. S. Rowlins on "Liquid and Liquid Mixtures" 2 nd ed., Butterworth, London (1969)

6) G. L.Bertrand, F. J. Millers, C.Wu, L. G. Hepler ; J.Phys. Chem., 70, 699(1966)

7) たとえば

G. Ne'me thy ; Angew. Chem. Intern. Ed. 5, 106 (1966)

8) C.H.F. Allen, C.V.Wills on, G.F. Frame ; J. Org.Chem., 7, 169(1942)

9) G. Némethy, H.A.Scheraga ; J.Phys. Chem., 66, $1773(1962)$

10) J. V. Hat ton, R. E. Richards ; Mol. Phys. 5, 139(1962)

11）高岸，片山，黒木; 緎学誌，25，411(1969) 